\title{
Muhasebe ve Finansman Öğretmenliği İçin Pedagojik Formasyon Eğitimi Alan Öğrencilerin Öğretmenlik Mesleğine ve Pedagojik Formasyon Eğitimine İlişskin Algıları
}

\section{The Perceptions Related to the Teaching Profession and Pedagogical Formation Education of the Students Who Are Taking Pedagogical Formation for Accounting and Finance Teaching}

\author{
Cuma Ercan a,* \\ ${ }^{a}$ Dr. Öğr. Üyesi, Kilis 7 Aralık Üniversitesi, İktisadi ve İdari Bilimler Fakültesi, İşletme Bölümü, 79000, Kilis/Türkiye. \\ ORCID: 0000-0001-7440-740X
}

\section{MAKALE BILGISİ}

Makale Geçmişi:

Başvuru tarihi: 19 Mayıs 2017

Düzeltme tarihi: 08 Kasım 2017

Kabul tarihi: 21 Kasım 2017

Anahtar Kelimeler:

Formasyon Eğitimi

Muhasebe ve Finansman

Öğretmenlik Mesleği

\section{A R T I C LE INFO}

Article history:

Received 19 May 2017

Received in revised form 08 November 2017

Accepted 21 November 2017

\section{Keywords:}

Formation Education

Accounting and Finance

Teaching Profession
ÖZ

Bu çalışmanın amacı, muhasebe ve finansman öğretmeni olmak için pedagojik formasyon eğitimi alan öğrencilerin öğretmenlik mesleğine ve pedagojik formasyon eğitimine ilişkin algı düzeylerini belirlemektir. Çalışma evrenini, 2016-2017 eğitim - öğretim yılında Kilis 7 Aralık Üniversitesi Eğitim Fakültesi'nde pedagojik formasyon eğitimi alan 101 öğrenci olușturmaktadır. Araștırma sonuçlarının değerlendirilmesinde SPSS istatistik programından yararlanılmıştır. Toplanan veriler; yüzde, frekans, aritmetik ortalama ve ki-kare testlerine tabi tutularak analiz edilmiştir. Araştırma sonuçlarına göre, muhasebe ve finansman öğretmenliği için pedagojik formasyon eğitimi alan öğrencilerin öğretmenlik mesleğine ve formasyon eğitimine ilişkin pozitif algıya sahip oldukları tespit edilmiştir. Bunun yanında öğrencilerin formasyon eğitimi ve öğretmenlik mesleğine ilişkin alg1 düzeylerinde cinsiyet, yaş ve bölüm değişkenlerine göre anlamlı bir farklılık gösterdiği tespit edilmiştir.

\begin{abstract}
A B S T R ACT
The purpose of this study is to determine the level of perceptions related to the teaching profession and pedagogical formation education of the students who took pedagogical formation to become accounting and finance teachers. The study universe covers 101 students who receive pedagogical training at the Faculty of Education of Kilis 7 Aralk University during the 2016-2017 academic year. Survey data were obtained through questionnaires. The SPSS statistical program was used in the evaluation of the research results. The collected data were analyzed by applying percentage, frequency, arithmetic mean, and chi-square tests. According to the results of the research, it was found that the students who had pedagogical formation training to become accounting and finance instructors had a positive perception about teaching profession and formation education. In addition, it was determined that there was a meaningful difference in perception level of students about formation education and teaching profession according to gender, age and department variables.
\end{abstract}

\section{Giriş}

Muhasebe ve finansman öğretmenliğine sadece Gazi Üniversitesi Ticaret ve Turizm Eğitim Fakültesi Muhasebe ve Finansman Öğretmenliği Bölümü ile İşletme Öğretmenliği Bölümü mezunları KPSS puanı ile atanmaktayd1. Ancak 13 Kasım 2009 tarihinde Teknik Eğitim Fakülteleri ve Mesleki Eğitim Fakülteleri kapatılmıştır. Böylece muhasebe ve finansman öğretmeni yetiştiren tek fakülte olan Gazi Üniversitesi Ticaret ve Turizm Eğitim Fakültesi de kapatılmış oldu. Muhasebe ve finansman öğretmenliğine ataması yapılan eğitim fakültesi mezunlarının sayılarının azalması ile birlikte iktisat, işletme ve maliye bölümü mezunlarına öğretmen olma yolu açılmış oldu. Ancak muhasebe ve finansman öğretmenliğine kaynak teşkil eden fakültelerin işletme, iktisat ve maliye bölümü mezunlarının öğretmen olarak atanabilmeleri için Pedagojik Formasyon Eğitimi Sertifikası Programını başarı ile tamamlamaları ve KPSS'den yeterli puan almaları gerekmektedir.

\footnotetext{
* Sorumlu yazar/Corresponding author.

e-posta: cercan@kilis.edu.tr
} 
Pedagojik formasyon, alan eğitimi almış kişilere alanlarını nasıl öğreteceklerine ilişkin eğitimin verilmesidir. Bu bağlamda pedagojik formasyon sürecinde öğrencilere alan eğitimi verilmemektedir. Bu nedenle öğrencilerin alanlarını çok iyi öğrenmiş olmaları gerekmektedir. Fakülte mezunlarına pedagojik formasyon eğitimi vererek öğretmen yetiştirme yaklaşımı, öncelikle alanında uzmanlaşmayı daha sonra ise alan bilgisinin nasıl öğretileceğini göstererek meslekte uzmanlaşmayı amaçlamaktadır. İngiltere, Kuzey Amerika, Avustralya, İsrail, Hindistan gibi ülkelerde de bu yaklaşımın çeşitli örneklerini görmek mümkündür (Wikipedia; Aktaran: Yıldırım ve Vural, 2013: 80). Teoride gayet mantıklı görünen bu yaklaşımın, uygulamada da aynı başarıyı göstermesi çok önemlidir. $\mathrm{Bu}$ nedenle pedagojik formasyon eğitimiyle ilgili her şey en ince ayrıntısına kadar planlanmalıdır. Planlama süreci sadece teoride kalmamalı, uygulamaya dönük mantıklı kararlar da alınabilmelidir. Buna bağlı olarak da daha önce uygulanmış ve başarısı görülmüş sistemlerin incelenmesinde fayda vardır (Yıldırım ve Vural, 2013: 81).

Türkiye'de pedagojik formasyon eğitimi, 2010-2011 öğretim yılından itibaren çeşitli fakültelerden mezun olan ya da üçüncü sınıfta öğrenim gören öğrencilere, 2.5 not ortalaması şartı ile verilmeye başlanmıştır (Altınkurt, Yllmaz ve Erol, 2014:51). Pedagojik formasyon eğitimi, Eğitim Bilimine Giriş, Program Geliştirme ve Öğretim, Gelişim Psikolojisi, Öğretim Teknolojileri ve Materyal Tasarımı, Ölçme ve Değerlendirme, Öğrenme Öğretme Kuram ve Yaklaşımları, Sınıf Yönetimi, Öğretmenlik Uygulamas1, Özel Öğretim Yöntemleri, Rehberlik gibi dersleri kapsamaktadır (Özer, 2016: 129)

Millî Eğitim Bakanlığı'nın öğretmenlik alanları, atama ve ders okutma esaslarına göre, Muhasebe ve Finansman Öğretmenliği ile İşletme Öğretmenliği bölümü mezunlarınca ihtiyacın karşılanamaması durumunda, formasyon eğitimi alan işletme, iktisat ve maliye bölümü mezunlarının atanabilecekleri belirtilmiştir (MEB, 2014: 23).

Bu çalışmada, muhasebe ve finansman öğretmeni olmak için pedagojik formasyon eğitimi alan öğrencilerin öğretmenlik mesleğine ve pedagojik formasyon eğitimine ilişkin alg1 düzeylerinin belirlenmesi amaçlanmıştır. Bu genel amaç çerçevesinde aşağıdaki sorulara cevaplar aranmıştır:

(i) Öğrencilerin pedagojik formasyon eğitimine ve öğretmenlik mesleğine ilişkin görüşleri nedir?

(ii) Öğrencilerin fakültede almış oldukları muhasebe ve finansman derslerinin öğretmenlik mesleğini yürütmede yeterlilik düzeyine ilişkin görüşleri nedir?

(iii) Öğrencilerin formasyon ve öğretmenlik algıları cinsiyet, yaş grubu ve bölüme göre anlamlı bir farklılık göstermekte midir?

\section{Literatür}

Literatürde pedagojik formasyonla ilgili birçok çalışma bulunmaktadır. Özellikle son yıllarda bu çalışmaların sayısının arttığı görülmektedir. Bu çalışmaların bazılarına aşağıda yer verilmiştir:

Taneri (2016), öğretmen adaylarının pedagojik formasyon eğitiminin niteliği hakkındaki görüşlerini araştırmış ve araştırma sonucunda öğretmen adaylarının yaklaşık yarısının derslerin içeriğini yararlı ve ilginç bulduğunu ortaya koymuştur.

Yıldız (2016), pedagojik formasyon eğitimi alan öğrencilerin uzaktan eğitime yönelik tutum düzeylerini belirlemek amacıyla bir araştırma yapmıştır. Araştırma sonucunda formasyon eğitimi alan öğrencilerin uzaktan eğitime ilişkin tutumları orta düzeyde çıkmıştır.

Özer (2016), pedagojik formasyon programı öğrencilerinde temel benlik değerlendirmesi, başa çıkma stratejileri ve yaşam doyumunu araştırmıştır. Yapılan araştırma sonucunda, temel benlik değerlendirmesi ve başa çıkma stratejileri ile yaşam doyumu arasında orta düzeyde ve anlamlı ilişkilenin olduğu ortaya çıkmıştır.

Çetinkaya ve Hatay (2016), pedagojik formasyon sertifika programı öğrencilerinin öğretmenlik mesleğine yönelik tutum ve aidiyet duygularının gelişmesinde formasyon eğitiminin ve öğretmenlik uygulaması dersinin etkisini araştırmışlar. Araştırmada, formasyon eğitiminin ve öğretmenlik uygulaması dersinin öğrencilerin büyük bir çoğunluğunun öğretmenlik mesleğine bakış açılarını olumlu yönde etkilediği sonucuna ulaşılmıştır.

Dadand1 vd. (2016), eğitim fakültesinde öğrenim gören öğretmen adayları ile pedagojik formasyon eğitimi alan öğretmen adaylarının öğretmenlik mesleğine karşı tutumlarını karşılaştırmışlar. Araştırma sonucunda, Eğitim Fakültesi öğrencilerinin mesleki kaygıları pedagojik formasyon alan öğrencilerden daha yükssek çıkmıştır.

Yalçın ve Akay (2015), eğitim fakültesinde okuyan öğretmen adayları ile pedagojik formasyon eğitimi alan öğretmen adaylarının öğretmenlik mesleği yeterliklerini incelemişler. Araştırma sonucuna göre, eğitim fakültesinde öğrenim gören öğretmen adaylarının kendilerini en çok yeterli buldukları alt yeterlikler; öğrencilere değer vermeanlama ve saygı göstermedir. Pedagojik formasyon programında öğrenim gören öğretmen adaylarının kendilerini en çok yeterli buldukları alt yeterlikler ise, öğrencilere değer verme, ulusal ve evrensel değerlere önem vermedir.

Altınkurt vd. (2014), pedagojik formasyon programı öğrencilerinin öğretmenlik mesleğine yönelik motivasyonlarını belirlemek amacıyla bir çalışma yapmıştır. Araştırma sonucunda, pedagojik formasyon programı öğrencilerinin öğretmenlik mesleğine yönelik motivasyonlarını yüksek bulmuşlar.

İlğan ve Sevinç (2013), pedagojik formasyon uygulamasına devam eden öğretmen adaylarının öğretmenlik mesleğine ilişkin tutumlarını belirlemek amacıyla bir araştırma yapmıştır. Araştırma sonucunda, öğretmen adaylarının öğretmenlik mesleğine ilişkin tutumlarının büyük ölçüde olumlu olduğu görülmüştür.

Polat (2013), pedagojik formasyon öğrencileri ile eğitim fakültesi öğrencilerinin öğretmenlik mesleğine yönelik tutumlarını karşılaştırmıştır. Polat yaptığı çalışmada, pedagojik formasyon öğrencilerinin öğretmenlik mesleğine yönelik tutumlarının eğitim fakültesi öğrencilerinden anlamlı olarak daha yüksek olduğu sonucuna varmıştır.

Yıldırım ve Vural (2013), Türkiye'de öğretmen yetiştirme ve pedagojik formasyon sorununu incelemişler. Yıldırım ve 
Vural adayların ortaöğretimi bitirip üniversite giriș sınavında başarılı olduktan sonra, yazılı giriş sınavı, yetenek testi, bireysel mülakat ve grup tartışmasının gözlenmesi aşamalarını içeren bir seçme sistemine tâbi tutularak Eğitim Fakültelerine alınmalarını önermektedirler.

Kartal ve Afacan (2012), pedagojik formasyon eğitimi alan öğretmen adaylarının öğretmenlik mesleğine ilişkin tutumlarını incelemişler. Araştırmada, pedagojik formasyon eğitimi alan öğretmen adaylarının öğretmenlik mesleğine yönelik genel tutumlarının orta düzeyin üzerinde olduğu ve öğretmenlik mesleğine yönelik olarak kendilerini \%60 oranında yeterli gördükleri sonucuna ulaşılmıştır.

Özkan (2012), formasyon programındaki öğretmen adaylarının öğretmenlik mesleğine ilişkin tutumlarını incelemiştir. Araştırma sonucunda; formasyon alan öğrencilerin öğretmenlik mesleğine ilgi duydukları, bu mesleği sevdikleri, mesleki bağlılıklarının üst düzeyde olduğu tespit edilmiştir.

Literatürde pedagojik formasyon eğitimi alan öğretmen adaylarının görüşlerine başvurulan birçok çalışma mevcuttur. Ancak bu çalışmaların hiçbirisinde sadece muhasebe ve finansman öğretmeni adaylarının görüşlerini içeren belirli bir çalışma bulunmamaktadır. Bu yönüyle çalışmanın alan yazına katkı sağlayacağı düşünülmektedir.

\section{Yöntem}

$\mathrm{Bu}$ araştırma, tarama modeli ile yapılmış betimsel bir çalışmadır. $\mathrm{Bu}$ bölümde araştırmanın amacı, evren ve örneklem, verilerin toplanması, analizi ve sınırlılıklara yer verilmiştir.

\subsection{Evren ve Örneklem}

$\mathrm{Bu}$ araştırmanın evrenini, 2016-2017 eğitim - öğretim yılında Kilis 7 Aralık Üniversitesi Muallim Rıfat Eğitim Fakültesinde muhasebe ve finansman öğretmenliği için pedagojik formasyon eğitimi alan öğrenciler oluşturmaktadır. Eğitim Fakültesinde muhasebe ve finansman öğretmenliği için toplam 101 öğrenci pedagojik formasyon eğitimi almaktadır. Örnekleme alınacak öğrencilerin seçiminde basit seçkisiz örnekleme tekniği kullanılmıştır. $\mathrm{Bu}$ kapsamda toplam 72 öğrenciye ulaşılmıştır. Örneklem çalışma evreninin \% 71,28'ine isabet etmektedir.

\subsection{Verilerin Toplanmas1}

Yapılan araştırmada veri toplama aracı olarak anket kullanılmıştır. Anket öğrenciler ile yüz yüze görüşülerek gerçekleştirilmiştir. Anket sorularının hazırlanmasında ise literatürde yapılan daha önceki çalışmalardan (Taneri, 2016; İlğan ve Sevinç, 2013; Altınkurt, vd., 2014) faydalanılmıştır. Anket iki bölümden oluşmaktadır. Birinci bölümde; katılımcıların demografik özellikleri ile ilgili sorulara, ikinci bölümde ise; öğretmenlik mesleğine ve formasyon eğitimine ilişkin sorulara yer verilmiştir. İkinci bölümdeki maddeler 5'li Likert tipinde düzenlenmiştir (1: Kesinlikle katılmıyorum,.......5: Kesinlikle katılıyorum).

\subsection{Verilerin Analizi}

Araştırmada elde edilen verilerin analizinde SPSS 18 istatistik paket programından yararlanılmıştır. Toplanan veriler; yüzde, frekans, aritmetik ortalama ve ki-kare bağımsızlık testlerine tabi tutularak analiz edilmiştir. Bağımsızlık testi için anlamlılık seviyesi 0,05 olarak belirlenmiştir.

\subsection{Sinırliliklar}

Araştırma 2016-2017 eğitim öğretim yılında Kilis 7 Aralık Üniversitesi'nde muhasebe ve finansman öğretmenliği için formasyon eğitimi alan toplam 101 öğrenci üzerinde yürütülmüştür.

\section{Bulgular ve Yorum}

\section{1. Öğrencilerin Demografik Özellikleri}

$\mathrm{Bu}$ bölümde araştırmaya katılan öğrencilerin demografik özellikleri ile bunlara ilişkin yorumlar yer almaktadır. Araştırmaya katılan öğretmen adaylarının demografik özelliklerine ilişkin frekans ve yüzde dağılımı Tablo 1'de verilmiştir.

Tablo 1. Öğrencilerin Demografik Özellikleri

\begin{tabular}{llcc}
\hline Değişken & Düzey & Frekans & Yüzde \\
\hline \multirow{2}{*}{ Cinsiyet } & Kadın & 52 & 72,2 \\
& Erkek & 20 & 27,8 \\
\hline \multirow{2}{*}{ Yaş } & $21-23$ & 40 & 55,6 \\
& $24-25$ & 10 & 13,9 \\
& 25 ve Üzeri & 22 & 30,6 \\
\hline \multirow{3}{*}{ Bölüm } & İşletme & 37 & 51,4 \\
& İktisat & 30 & 41,7 \\
& Maliye & 5 & 6,9 \\
\hline \multirow{2}{*}{ Ŏgrenim Durumu } & Son Sinıf & 36 & 50,0 \\
& Lisans Mezunu & 35 & 48,6 \\
& Yüksek lisans & 1 & 1,4 \\
\hline \multirow{2}{*}{ Formasyon Alma } & Öğretmenlik İçin & 62 & 86,1 \\
Sebebi & Kişisel Gelişim & 7 & 9,7 \\
& Diğer & 3 & 4,2 \\
\hline
\end{tabular}

Tablo 1'de görüldüğü üzere, ankete katılan öğretmen adaylarının \%72,2'si kadın, \%27,8'i erkektir. Katılımcıların \%56,6's1 21-23 yaş, \%13,9'u 24-25 yaş ve \%30,6's1 25 ve üzeri yaş aralığındadır. Öğretmen adaylarının \%51,4'ü işletme, \%41,7'si iktisat, \%6,9'u maliye bölümündendir. Ayrıca adayların \%50'si son sınıf, \%48,6'sı lisans, \% 1,4'ü ise yüksek lisans mezunudur. Öğretmen adaylarının büyük bir çoğunluğu $(\% 86,1)$ pedagojik formasyon eğitimini öğretmenlik için alırken, \%9,7'si kişisel gelişim, \%4,2'si ise diğer sebeplerden dolayı almaktadır.

\section{2. Öğrencilerin Pedagojik Formasyona İlişkin Görüşleri}

$\mathrm{Bu}$ bölümde, araştırmaya katılan öğrencilerin pedagojik formasyon eğitimine ilişkin algı düzeylerini ölçen 11 ifade yer almaktadır. Öğretmen adaylarının bu ifadelere katılma dereceleri frekans ve yüzde olarak Tablo 2'de gösterilmiştir. 
Tablo 2. Pedagojik Formasyon Eğitimi Algısı Anketine Ait Yüzde ve Frekans Değerleri

\begin{tabular}{|c|c|c|c|c|c|c|c|}
\hline İfadeler & & 5 & 4 & 3 & 2 & 1 & Top. \\
\hline \multirow{2}{*}{$\begin{array}{l}\text { Pedagojik formasyon } \\
\text { eğitimi öğretmenlik } \\
\text { için gereklidir. }\end{array}$} & Frekans & 44 & 23 & 1 & 3 & 1 & 72 \\
\hline & Yüzde & 61,1 & 31,9 & 1,4 & 4,2 & 1,4 & 100 \\
\hline \multirow{2}{*}{$\begin{array}{l}\text { Pedagojik formasyon } \\
\text { eğitimi öğretmenlik } \\
\text { için yetersizdir. }\end{array}$} & Frekans & 4 & 13 & 24 & 20 & 11 & 72 \\
\hline & Yüzde & 5,6 & 18 & 33,3 & 27,8 & 15,3 & 100 \\
\hline \multirow{2}{*}{$\begin{array}{l}\text { Muhasebe ve } \\
\text { finansman bilgisi } \\
\text { pedagojik formasyon } \\
\text { bilgisinden daha } \\
\text { önemlidir. }\end{array}$} & Frekans & 17 & 31 & 6 & 16 & 2 & 72 \\
\hline & Yüzde & 23,6 & 43,1 & 8,3 & 22,2 & 2,8 & 100 \\
\hline \multirow{2}{*}{$\begin{array}{l}\text { Pedagojik formasyon } \\
\text { derslerinin içeriği } \\
\text { güncel değildir. }\end{array}$} & Frekans & 3 & 13 & 21 & 26 & 9 & 72 \\
\hline & Yüzde & 4,2 & 18 & 29,2 & 36,1 & 12,5 & 100 \\
\hline \multirow{2}{*}{$\begin{array}{l}\text { Pedagojik formasyon } \\
\text { eğitimi kişisel } \\
\text { gelişimime katkı } \\
\text { sağladı. }\end{array}$} & Frekans & 39 & 26 & 5 & 1 & 1 & 72 \\
\hline & Yüzde & 54,2 & 36,1 & 6,9 & 1,4 & 1,4 & 100 \\
\hline \multirow{2}{*}{$\begin{array}{l}\text { Pedagojik formasyon } \\
\text { muhasebe ve } \\
\text { finansman bilgilerini } \\
\text { ögretmenlikte nasıl } \\
\text { kullanacağımı } \\
\text { gösteriyor. }\end{array}$} & Frekans & 20 & 33 & 9 & 7 & 3 & 72 \\
\hline & Yüzde & 27,8 & 45,8 & 12,5 & 9,7 & 4,2 & 100 \\
\hline \multirow{2}{*}{$\begin{array}{l}\text { Pedagojik formasyon } \\
\text { eğitimi öğretmenlik } \\
\text { mesleğine bakış açımı } \\
\text { olumlu yönde etkiledi. }\end{array}$} & Frekans & 34 & 31 & 2 & 3 & 2 & 72 \\
\hline & Yüzde & 47,2 & 43 & 2,8 & 4,2 & 2,8 & 100 \\
\hline \multirow{2}{*}{$\begin{array}{l}\text { Pedagojik formasyon } \\
\text { eğitiminde teoriye } \\
\text { ağırlık verilmektedir. }\end{array}$} & Frekans & 7 & 32 & 17 & 14 & 2 & 72 \\
\hline & Yüzde & 9,7 & 44,5 & 23,6 & 19,4 & 2,8 & 100 \\
\hline \multirow{2}{*}{$\begin{array}{l}\text { Pedagojik formasyon } \\
\text { eğitiminde sınıf içinde } \\
\text { daha fazla uygulama } \\
\text { yapılmalıdır. }\end{array}$} & Frekans & 22 & 37 & 7 & 4 & 2 & 72 \\
\hline & Yüzde & 30,6 & 51,4 & 9,6 & 5,6 & 2,8 & 100 \\
\hline \multirow{2}{*}{$\begin{array}{l}\text { Staj uygulamaları } \\
\text { haftada birkaç güne } \\
\text { yayılmalıdır. }\end{array}$} & Frekans & 14 & 21 & 9 & 17 & 11 & 72 \\
\hline & Yüzde & 19,4 & 29,2 & 12,5 & 23,6 & 15,3 & 100 \\
\hline $\begin{array}{l}\text { Staj uygulamaları } \\
\text { muhasebe ve }\end{array}$ & Frekans & 51 & 14 & 4 & 2 & 1 & 72 \\
\hline $\begin{array}{l}\text { finansman derslerinde } \\
\text { yapılmalıdır. }\end{array}$ & Yüzde & 70,8 & 19,4 & 5,6 & 2,8 & 1,4 & 100 \\
\hline
\end{tabular}

Tablo 2'de görüldüğü gibi, "pedagojik formasyon eğitimi öğretmenlik için gereklidir" ifadesine öğretmen adaylarının büyük bir çoğunluğu (\%93) katılırken, "pedagojik formasyon eğitimi öğretmenlik için yetersizdir" ifadesine ise sadece \%23,6's1 katılmaktadır. Bu bulgulara göre, pedagojik formasyon eğitiminin öğretmenlik için hem gerekli hem de yeterli olduğunu belirtilebilir.

Tablo 2'de görüldüğü gibi, “muhasebe ve finansman bilgisi pedagojik formasyon bilgisinden daha önemlidir" ifadesine öğretmen adaylarının \%66,7'si katılırken, \%25'i katılmamakta ve \%8,3'ü kararsız kalmaktadır. Bu durumda, muhasebe ve finansman öğretmenliği için alan bilgisinin formasyondan daha önemli olduğu ifade edilebilir.

Diğer taraftan "pedagojik formasyon derslerinin içeriği güncel değildir" ifadesine öğretmen adaylarının \%22,2'si katılırken, \%48,6'sı katılmamakta ve \%29,2'si ise kararsız kalmaktadır. Ayrıca öğretmen adaylarının büyük bir çoğunluğu $(\% 90,3)$ pedagojik formasyon eğitiminin kişisel gelişime katkı sağladığ1 görüşündedirler.

Öğretmen adaylarının çoğunluğu $(\% 73,6)$ pedagojik formasyon eğitiminin muhasebe ve finansman bilgilerini öğretmenlikte nasıl kullanılacağını gösterdiği görüşündeler. Ayrıca pedagojik formasyon eğitimi katılımcıların büyük çoğunluğunun (\%90) öğretmenlik mesleğine bakış açılarını olumlu yönde etkilemiştir.

Diğer taraftan "pedagojik formasyon eğitiminde teoriye ağırlık verilmektedir" ifadesine öğretmen adaylarının \%54,2'si katılırken, \%22,2'si katılmamakta ve \%23,6's1 kararsız kalmaktadır. Ayrıca öğretmen adaylarının çoğunluğu (\%82) sınıf içinde daha fazla uygulama yapılmasını istemektedir.

Öğretmen adaylarına haftanın bir gününde yapılan staj uygulamalarının birkaç güne dağıtılması hakkındaki görüşleri sorulmuştur. Adayların sadece \%48,6'sı bu fikre katılmaktadır. Adayların büyük bir çoğunluğu $(\% 90,2)$ staj uygulamalarının muhasebe ve finansman derslerinde yapılması gerektiği görüşündedirler.

Tablo 3. Pedagojik Formasyon Eğitimi Algısı Anketine Ait Aritmetik Ortalama ve Standart Sapma Değerleri

\begin{tabular}{lcc}
\hline İfadeler & X & SS \\
\hline $\begin{array}{l}\text { Pedagojik formasyon eğitimi öğretmenlik } \\
\text { için gereklidir. }\end{array}$ & 4,47 &, 839 \\
$\begin{array}{l}\text { Pedagojik formasyon eğitimi öğretmenlik } \\
\text { için yetersizdir. }\end{array}$ & 2,71 & 1,106 \\
$\begin{array}{l}\text { Muhasebe ve finansman bilgisi pedagojik } \\
\text { formasyon bilgisinden daha önemlidir. }\end{array}$ & 3,63 & 1,156 \\
$\begin{array}{l}\text { Pedagojik formasyon derslerinin içeriği } \\
\text { güncel değildir. }\end{array}$ & 2,65 & 1,050 \\
$\begin{array}{l}\text { Pedagojik formasyon eğitimi kişisel } \\
\text { gelişimime katkı sağladı. }\end{array}$ & 4,40 &, 799 \\
$\begin{array}{l}\text { Pedagojik formasyon eğitimi muhasebe ve } \\
\text { finansman bilgilerini öğretmenlikte nasıl } \\
\text { kullanacağımı gösteriyor. }\end{array}$ & 3,83 & 1,075 \\
$\begin{array}{l}\text { Pedagojik formasyon eğitimi öğretmenlik } \\
\text { mesleğine bakış açımı olumlu yönde } \\
\text { etkiledi. }\end{array}$ & 4,28 &, 923 \\
$\begin{array}{l}\text { Pedagojik formasyon eğitiminde teoriye } \\
\text { ağırlı verilmektedir. }\end{array}$ & 3,39 & 1,001 \\
$\begin{array}{l}\text { Pedagojik formasyon eğitiminde sınıf } \\
\text { içinde daha fazla uygulama yapılmalıdır. }\end{array}$ & 4,01 &, 942 \\
$\begin{array}{l}\text { Staj uygulamaları haftada birkaç güne } \\
\text { yayılmalıdır. }\end{array}$ & 3,14 & 1,387 \\
$\begin{array}{l}\text { Staj uygulamaları muhasebe ve finansman } \\
\text { derslerinde yapılmalıdır. }\end{array}$ & 4,56 &, 837 \\
\begin{tabular}{l} 
Toplam \\
\hline
\end{tabular} & 3,73 &, 401 \\
\hline
\end{tabular}

Tablo 3'te görüldüğü gibi, öğretmen adayları pedagojik formasyon eğitimi ile ilgili genel olarak pozitif bir algıya sahiptir $(\bar{x}=3,73)$. Tabloda da görüldüğü gibi öğretmen adayları 10 ifade için pozitif algıya, 2 ifade için negatif algıya sahiptirler. En yüksek ortalama "staj uygulamaları muhasebe ve finansman derslerinde yapılmalıdır" ifadesine aittir $(\bar{x}=4,56)$. Bu ifadeye katılımın en yüksek seviyede çıkmasında staj uygulamalarının matematik dersinde yapılmasının etkisinin olduğu düşünülmektedir. Diğer taraftan, en düşük ortalama ise, "pedagojik formasyon derslerinin içeriği güncel değildir" ifadesine aittir $(\bar{x}=2,65)$. Öğretmen adaylarının bu ifadeyle ilgili negatif bir algıya 
sahip oldukları görülmektedir. Buna göre öğretmen adaylarının pedagojik formasyon derslerinin içeriğini güncel gördükleri ifade edilebilir.

\section{3. Öğrencilerin Öğretmenlik Mesleğine İlişkin Görüşleri}

$\mathrm{Bu}$ bölümde, araştırmaya katılan öğrencilerin öğretmenlik mesleğine ilişkin görüşlerini içeren 8 adet ifade bulunmaktadır. Öğretmen adaylarının bu ifadelere katılma dereceleri frekans ve yüzde olarak Tablo 4'te gösterilmiştir.

Tablo 4. Öğretmenlik Mesleği Algısı Anketine Ait Maddelerin Yüzde ve Frekans Değerleri

\begin{tabular}{|c|c|c|c|c|c|c|c|}
\hline \multicolumn{2}{|l|}{ İfadeler } & 5 & 4 & 3 & 2 & 1 & Top. \\
\hline \multirow{2}{*}{$\begin{array}{l}\text { İ̈BF mezunları } \\
\text { formasyon eğitiminden } \\
\text { sonra iyi birer } \\
\text { öğretmen olur. }\end{array}$} & Frekans & 23 & 32 & 13 & 2 & 2 & 72 \\
\hline & Yüzde & 31,9 & 44,4 & 18,1 & 2,8 & 2,8 & 100 \\
\hline \multirow{2}{*}{$\begin{array}{l}\text { Öğretmenlik toplumda } \\
\text { saygınlığı olan bir } \\
\text { meslektir. }\end{array}$} & $\mathrm{F}$ & 47 & 21 & 3 & 1 & - & 72 \\
\hline & Yüzde & 65,3 & 29,2 & 4,2 & 1,4 & -- & 100 \\
\hline \multirow{2}{*}{$\begin{array}{l}\text { Öğretmenlik mesleğini } \\
\text { çok seviyorum. }\end{array}$} & Frekans & 35 & 35 & 2 & -- & -- & 72 \\
\hline & Yüzde & 48,6 & 48,6 & 2,8 & -- & -- & 100 \\
\hline \multirow{2}{*}{$\begin{array}{l}\text { Gelecekte öğretmenlik } \\
\text { mesleği daha popüler } \\
\text { olacaktır. }\end{array}$} & $\mathrm{F}$ & 22 & 23 & 20 & 5 & 2 & 72 \\
\hline & Yüzde & 30,6 & 31,9 & 27,8 & 6,9 & 2,8 & 100 \\
\hline \multirow{2}{*}{$\begin{array}{l}\text { Öğretmenlik çok sıkıcı } \\
\text { ve sıradan bir } \\
\text { meslektir. }\end{array}$} & $\mathrm{F}$ & -- & 3 & 5 & 24 & 40 & 72 \\
\hline & Yüzde & -- & 4,2 & 6,9 & 33,3 & 55,6 & 100 \\
\hline \multirow{2}{*}{$\begin{array}{l}\text { Fakültede aldığım } \\
\text { muhasebe ve } \\
\text { finansman dersleri } \\
\text { öğretmenlik için } \\
\text { yeterlidir. } \\
\end{array}$} & Frekans & 11 & 22 & 22 & 13 & 4 & 72 \\
\hline & Yüzde & 15,3 & 30,5 & 30,5 & 18,1 & 5,6 & 100 \\
\hline \multirow{2}{*}{$\begin{array}{l}\text { Hiçbir iş bulamazsam } \\
\text { ögrretmenlik yapmayı } \\
\text { düşünüyorum. }\end{array}$} & Frekans & 14 & 13 & 10 & 24 & 11 & 72 \\
\hline & Yüzde & 19,4 & 18,1 & 13,9 & 33,3 & 15,3 & 100 \\
\hline \multirow{2}{*}{$\begin{array}{l}\text { Öğretmenlik çok } \\
\text { fedakârlık gerektiren } \\
\text { bir meslektir. } \\
\end{array}$} & Frek & 54 & 15 & 2 & -- & 1 & 72 \\
\hline & Yüzde & 75,0 & 20,8 & 2,8 & -- & 1,4 & 100 \\
\hline
\end{tabular}

Tablo 4'te görüldüğü gibi, öğretmen adaylarının çoğunluğu $(\% 76,3)$ İİBF mezunlarının formasyon eğitiminden sonra iyi birer öğretmen olacağına inanmaktadır. Ayrıca katılımcıların büyük bir çoğunluğu $(\% 94,5)$ öğretmenliğin toplumda saygınlığı olan bir meslek olduğunu ve yine büyük bir çoğunluğu $(\% 97,2)$ öğretmenlik mesleğini çok sevdiğini belirtmektedir.

Diğer taraftan, "gelecekte öğretmenlik mesleği daha popüler olacaktır” ifadesine öğretmen adaylarının \%62,5'i katılırken, $\% 9,7$ 'si katılmamakta ve \%27,8'i kararsiz kalmaktadır. Ayrıca "öğretmenlik çok sıkıcı ve sıradan bir meslektir" ifadesine adayların çok az bir kısmı $(\% 4,2)$ katılmaktadır.

Yukarıdaki bulgulara göre, "fakültede aldığım muhasebe ve finansman dersleri öğretmenlik için yeterlidir" ifadesine öğretmen adaylarının \%45,8'i katılırken,\%23,7'si katılmamakta, \%30,5'i ise kararsız kalmaktadır.

"Hiçbir iş bulamazsam öğretmenlik yapmayı düşünüyorum" ifadesine öğretmen adaylarının \%37,5'i katılırken, \% 48,6's1 katılmamakta, \%13,9'u ise kararsız kalmaktadır. Ayrıca adaylarının büyük bir çoğunluğu $(\% 95,8)$ öğretmenliğin çok fedakârlık gerektiren bir meslek olduğu görüşündedirler.
Öğretmen adaylarının öğretmenlik mesleği ile ilgili algılarının ortalamaları ve standart sapmaları Tablo 5'te verilmiştir.

Tablo 5. Öğretmenlik Mesleği Algısı Anketine Ait Aritmetik Ortalama ve Standart Sapma Değerleri

\begin{tabular}{|c|c|c|}
\hline fadeler & $\mathrm{X}$ & SS \\
\hline $\begin{array}{l}\text { BF mezunları formasyon eğitiminden sonra iyi birer } \\
\text { ğretmen olur. }\end{array}$ & 4,00 & 934 \\
\hline Öğretmenlik toplumda saygınlığı olan bir meslektir. & 4,58 & 645 \\
\hline lik mesleğin & 4,46 &, 555 \\
\hline $\begin{array}{l}\text { Gelecekte öğretmenlik mesleği daha popüler } \\
\text { olacaktır. }\end{array}$ & 3,81 & 1,043 \\
\hline Öğretmenlik çok sıkıcı ve sıradan bir meslekti & 1 , & ,799 \\
\hline be ve finansman dersleri & 3,32 & 1,1 \\
\hline $\begin{array}{l}\text { Hiçbir iş bulamazsam öğretmenlik yapmayı } \\
\text { düşünüyorum. }\end{array}$ & 2,93 & 1,3 \\
\hline ğretme & 4,68 & ,668 \\
\hline Toplam & 3,67 & ,379 \\
\hline
\end{tabular}

Tablo 5'te görüldüğü gibi, araștırmaya katılan öğretmen adayları öğretmenlik mesleği ile ilgili genel olarak pozitif bir algıya sahiptir $(\bar{x}=3,67)$. Tabloda da görüldüğü gibi öğretmen adayları 2 ifade için negatif algıya sahipken, diğer ifadeler için pozitif algıya sahiptirler. En yüksek ortalama $(\bar{x}=4,68)$ "öğretmenlik çok fedakârlık gerektiren bir meslektir" ifadesine ait iken, en düşük ortalama $(\bar{x}=1,60)$ "öğretmenlik çok sıkıcı ve sıradan bir meslektir" ifadesine aittir.

\subsection{Ki-Kare Analiz Sonuçları}

Bu bölümde öğrencilerin ankette yer alan her bir maddeye katılma durumu cinsiyet, yaş grubu ve bölüme göre farklılık gösterip göstermediği ki-kare testi yardımıyla analiz edilmiştir. Analiz sonuçları değişkenlere göre aşağıda sıralanmıştır. Çapraz tabloların ki-kare değerlerine ilişkin anlamlılık düzeyleri, daha önce de ifade edildiği gibi yüzde beş $(0,05)$ olarak belirlenmiştir.

\subsubsection{Cinsiyet Değişkenine Göre}

Cinsiyet değişkeni ile ankette yer alan maddeler arasındaki ilişkinin ki-kare analiz sonuçları Tablo 6'da verilmişstir.

Tablo 6. Cinsiyet Değişkeni İle Maddeler Arasındaki Ki-Kare Analizi Sonuçları

\begin{tabular}{lccc}
\hline & $\begin{array}{l}\text { Ki-kare } \\
\text { Değeri }\end{array}$ & $\mathrm{Sd}$ & $\mathrm{p}$ \\
\hline $\begin{array}{l}\text { Pedagojik Formasyon eğitiminin } \\
\text { öğretmenlik için gereklidir. }\end{array}$ & 3,069 & 4 &, 546 \\
$\begin{array}{l}\text { Pedagojik Formasyon eğitimi öğretmenlik } \\
\text { için yetersizdir. }\end{array}$ & 1,431 & 4 &, 839 \\
\hline $\begin{array}{l}\text { Muhasebe ve finansman bilgisi pedagojik } \\
\text { formasyon bilgisinden daha önemlidir. }\end{array}$ & 2,582 & 4 &, 630 \\
$\begin{array}{l}\text { Pedagojik Formasyon derslerinin içeriği } \\
\text { güncel değildir. }\end{array}$ & 1,728 & 4 &, 786 \\
$\begin{array}{l}\text { Pedagojik Formasyon eğitimi kişisel } \\
\text { gelişimime katk1 sağladı. }\end{array}$ & 3,902 & 4 &, 419 \\
$\begin{array}{l}\text { Pedagojik formasyon eğitimi muhasebe ve } \\
\text { finansman bilgilerini öğretmenlikte nasıl } \\
\text { kullanacağımı gösteriyor. }\end{array}$ & 4,888 & 4 &, 299 \\
\hline
\end{tabular}


Pedagojik Formasyon öğretmenlik

mesleğine bakış açımı olumlu yönde etkiledi.

$11,513 \quad 4 \quad, 021^{*}$

Pedagojik formasyon eğitiminde teoriye

ağırlık verilmektedir.

$1,561 \quad 4 \quad, 816$

Pedagojik Formasyon eğitiminde sınıf

içinde daha fazla uygulama yapılmalıdır. $\quad 3,165 \quad 4 \quad, 531$

Staj uygulamaları haftada birkaç güne

yayilmalidir

$, 984 \quad 4 \quad, 912$

İ̈BF mezunlarının formasyon eğitiminden

sonra iyi birer öğretmen olur.

$1,524 \quad 4 \quad, 822$

Öğretmenlik toplumda saygınlığı olan bir

meslektir.

$2,811 \quad 3 \quad, 422$

\begin{tabular}{llll}
\hline Öğretmenlik mesleğini çok seviyorum. & 2,287 & 2 &, 319
\end{tabular}

Gelecekte öğretmenlik mesleğinin daha

popüler olacaktır.

$6,070 \quad 4 \quad, 194$

Öğretmenlik çok sıkıcı ve sıradan bir

meslektir.

$1,218 \quad 3 \quad 749$

Fakültede aldığım muhasebe ve finansman

dersleri öğretmenlik için yeterlidir.

$2,154 \quad 4 \quad, 707$

Hiçbir iș bulamazsam öğretmenlik yapmayı

düşünüyorum.

$9,174 \quad 4 \quad 057$

Öğretmenlik çok fedakarlık gerektiren bir

meslektir.

$2,806 \quad 3 \quad 422$

Staj uygulamaları muhasebe ve finansman

derslerinde yapılmalıdır.

$2,488 \quad 4 \quad, 647$

$\mathrm{x}^{2}=11,513 \mathrm{Sd}=4 \mathrm{p}=, 021$

Tablo 6 incelendiğinde cinsiyet değişkeni ile ankette yer alan maddelerden sadece "pedagojik formasyon eğitimi öğretmenlik mesleğine bakış açımı olumlu yönde etkiledi" ifadesi arasında 0.05 anlam düzeyinde istatistiksel açıdan anlamlı bir fark bulunmuştur $\left(\mathrm{x}^{2}=11,513\right.$ ve $\left.\mathrm{p}<0,05\right)$. Cinsiyet ile söz konusu ifade arasındaki çapraz tablo değerleri aşağıda verilmiştir.

Tablo 7: Pedagojik Formasyon Eğitiminin Öğretmenlik Mesleğine Bakış Açısını Olumlu Yönde Etkilemesi Durumu

\begin{tabular}{|c|c|c|c|c|c|}
\hline Yanitlar & \multicolumn{2}{|c|}{ Kadın } & \multicolumn{2}{|c|}{ Erkek } & Topla \\
\hline & reka & Yüzd & Frekans & Yüzde & \\
\hline Kesinlikle Katıliyorum & 23 & 44,2 & 11 & 55 & 43 \\
\hline Kat1liyorum & 26 & 50 & 5 & 25 & 37 \\
\hline Kararsızım & 1 & 2 & 1 & 2,5 & 6 \\
\hline Kat1li & - & - & 3 & 15 & 1 \\
\hline Kesinlikle Katılmıyorum & 2 & 3,8 & - & - & 2 \\
\hline Toplam & 52 & 100 & 20 & 100 & 72 \\
\hline
\end{tabular}

$\mathrm{x}^{2}=11,513 \quad \mathrm{Sd}=4 \quad \mathrm{p}=, 021$

Tablo 7'deki bulgulara göre, her iki cinsiyet düzeyinde de pedagojik formasyon eğitiminin öğretmenlik mesleğine bakış açılarını olumlu yönde etkilediği görülmektedir. Ancak kadınların $(\% 94,2)$ erkeklere ( \% 80) göre daha fazla etkilendiği görülmektedir.

\subsubsection{Yaş Değişkenine Göre}

Yaş değişkeni ile ankette yer alan maddeler arasındaki ilişkinin ki-kare analiz sonuçları Tablo 8'de verilmiştir.

Tablo 8: Yaş Değişkeni ile Maddeler Arasındaki Ki-Kare Analizi Sonuçları

\begin{tabular}{lccc}
\hline & $\begin{array}{c}\text { Ki-kare } \\
\text { Değeri }\end{array}$ & $\mathrm{pd}$ \\
\hline $\begin{array}{l}\text { Pedagojik Formasyon eğitiminin } \\
\text { öğretmenlik için gereklidir. }\end{array}$ & 3,732 & 8 &, 880 \\
\hline $\begin{array}{l}\text { Pedagojik Formasyon eğitimi öğretmenlik } \\
\text { için yetersizdir. }\end{array}$ & 11,653 & 8 &, 167 \\
\hline
\end{tabular}

\begin{tabular}{|c|c|c|c|}
\hline $\begin{array}{l}\text { Muhasebe ve finansman bilgisi pedagojik } \\
\text { formasyon bilgisinden daha önemlidir. }\end{array}$ & 4,898 & 8 & ,768 \\
\hline $\begin{array}{l}\text { Pedagojik Formasyon derslerinin içeriği } \\
\text { güncel değildir. }\end{array}$ & 13,550 & 8 & ,094 \\
\hline $\begin{array}{l}\text { Pedagojik Formasyon eğitimi kişisel } \\
\text { gelişimime katkı sağladı. }\end{array}$ & 12,987 & 8 &, 112 \\
\hline $\begin{array}{l}\text { Pedagojik formasyon eğitimi muhasebe ve } \\
\text { finansman bilgilerini öğretmenlikte nasıl } \\
\text { kullanacağımı gösteriyor. }\end{array}$ & 17,332 & 8 &, $027 *$ \\
\hline $\begin{array}{l}\text { Pedagojik Formasyon öğretmenlik } \\
\text { mesleğine bakış açımı olumlu yönde } \\
\text { etkiledi. }\end{array}$ & 13,553 & 8 & ,094 \\
\hline $\begin{array}{l}\text { Pedagojik formasyon eğitiminde teoriye } \\
\text { ağırlık verilmektedir. }\end{array}$ & 3,298 & 8 & ,914 \\
\hline $\begin{array}{l}\text { Pedagojik Formasyon eğitiminde sınıf içinde } \\
\text { daha fazla uygulama yapılmalıdır. }\end{array}$ & 10,063 & 8 &, 261 \\
\hline $\begin{array}{l}\text { Staj uygulamaları haftada birkaç güne } \\
\text { yayılmalıdır }\end{array}$ & 20,207 & 8 &, $010^{*}$ \\
\hline $\begin{array}{l}\text { İİBF mezunlarının formasyon eğitiminden } \\
\text { sonra iyi birer öğretmen olur. }\end{array}$ & 5,290 & 8 &, 726 \\
\hline $\begin{array}{l}\text { Öğretmenlik toplumda saygınlığı olan bir } \\
\text { meslektir. }\end{array}$ & 12,842 & 6 &, $046^{*}$ \\
\hline Öğretmenlik mesleğini çok seviyorum. & 5,449 & 4 & ,244 \\
\hline $\begin{array}{l}\text { Gelecekte öğretmenlik mesleğinin daha } \\
\text { popüler olacaktır. }\end{array}$ & 20,296 & 8 &, $009^{*}$ \\
\hline $\begin{array}{l}\text { Öğretmenlik çok sıkıcı ve sıradan bir } \\
\text { meslektir. }\end{array}$ & 2,945 & 6 &, 816 \\
\hline $\begin{array}{l}\text { Fakültede aldığım muhasebe ve finansman } \\
\text { dersleri öğretmenlik için yeterlidir. }\end{array}$ & 7,961 & 8 & ,437 \\
\hline $\begin{array}{l}\text { Hiçbir iş bulamazsam öğretmenlik yapmayı } \\
\text { düşünüyorum. }\end{array}$ & 11,324 & 8 &, 184 \\
\hline $\begin{array}{l}\text { Öğretmenlik çok fedakarlık gerektiren bir } \\
\text { meslektir. }\end{array}$ & 3,103 & 6 & ,796 \\
\hline $\begin{array}{l}\text { Staj uygulamaları muhasebe ve finansman } \\
\text { derslerinde yapılmalıdır. }\end{array}$ & 16,725 & 8 &, $033^{*}$ \\
\hline
\end{tabular}

Tablo 8 incelendiğinde, yaş değişkeni ile ankette yer alan beş ifade arasında 0.05 anlam düzeyinde istatistiksel açıdan anlamlı bir fark olduğu görülmektedir. Bunlar: Pedagojik formasyon eğitimi fakültede aldığım muhasebe ve finansman bilgilerini öğretmenlikte nasıl kullanacağımı gösteriyor $\left(x^{2}=17,332\right.$ ve $\left.p=, 027\right)$, staj uygulamaları haftada birkaç güne yayılmalıdır $\left(\mathrm{x}^{2}=20,207 \mathrm{ve} p=, 010\right)$, ö ğretmenlik toplumda saygınlığı olan bir meslektir $\left(x^{2}=12,842\right.$ ve $\mathrm{p}=, 046)$, gelecekte öğretmenlik mesleği daha popüler olacaktır $\left(x^{2}=20,296\right.$ ve $\left.p=, 009\right)$ ve staj uygulamaları muhasebe ve finansman derslerinde yapılmalıdır $\left(\mathrm{x}^{2}=16,725\right.$ ve $p=, 033)$. Söz konusu ifadelere ilişkin çapraz tablo değerleri aşağıda verilmiştir.

Tablo 9: Pedagojik Formasyon Eğitiminin Fakültede Alınan Muhasebe ve Finansman Bilgilerinin Nasıl Kullanılacağını Gösterme Durumu

\begin{tabular}{|c|c|c|c|c|c|c|}
\hline \multirow[t]{2}{*}{ Yanitlar } & \multicolumn{2}{|c|}{ 21-23 Yaş } & \multicolumn{2}{|c|}{ 24-25 Yaş } & \multicolumn{2}{|c|}{25 Yaş ve Üzeri } \\
\hline & Frekans & Yüzde & Frekans & Yüzde & Frekans & Yüzde \\
\hline $\begin{array}{l}\text { Kesinlikle } \\
\text { Katılıyorum }\end{array}$ & 8 & 20 & 3 & 30 & 9 & 41 \\
\hline Kat1lyyorum & 18 & 45 & 2 & 20 & 13 & 59 \\
\hline Kararsızım & 7 & 17,5 & 2 & 30 & - & $\begin{array}{lll}- & -\end{array}$ \\
\hline Katılmiyorum & 4 & 10 & 3 & 30 & - & - \\
\hline $\begin{array}{l}\text { Kesinlikle } \\
\text { Katılmiyorum }\end{array}$ & 3 & 7,5 & - & - & - & - \\
\hline Toplam & 40 & 100 & 10 & 100 & 22 & 100 \\
\hline
\end{tabular}

$\mathrm{x}^{2}=17,332 \quad \mathrm{Sd}=8 \quad \mathrm{p}=, 027$ 
Yukarıdaki tabloda da görüldüğü gibi, "pedagojik formasyon eğitimi muhasebe ve finansman bilgilerini öğretmenlikte nasıl kullanacağımı gösteriyor" ifadesine 25 ve üzeri yaş grubunun tamamı katılırken, 21-23 yaş grubunun $\% 65$ ' $\mathrm{i}, 24-25$ yaş grubunun ise \% 50 'si katılmaktadır. Kararsızlık durumunun ise en fazla 24-25 yaş grubunda (\% 20) olduğu tespit edilmiştir.

Tablo 10: Staj Uygulamalarının Haftada Birkaç Güne Dağılımı Durumu

\begin{tabular}{|c|c|c|c|c|c|c|}
\hline Yanitlar & $21-23$ & Yaş & $24-25$ & Yaş & 25 Yaş v & e Üzeri \\
\hline & Frekans & Yüzde & Frekans & Yüzde & Frekans & Yüzde \\
\hline $\begin{array}{l}\text { Kesinlikle } \\
\text { Kat1liyorum }\end{array}$ & 13 & 32,5 & 1 & 10 & - & - \\
\hline Kat1liyorum & 12 & 30 & 1 & 10 & 8 & 36,5 \\
\hline Kararsızım & 3 & 7,5 & 4 & 40 & 2 & 9 \\
\hline Katılmiyorum & 6 & 15 & 3 & 30 & 8 & 36,5 \\
\hline $\begin{array}{l}\text { Kesinlikle } \\
\text { Kat1lmiyorum }\end{array}$ & 6 & 15 & 1 & 10 & 4 & 18 \\
\hline Toplam & 40 & 100 & 10 & 100 & 22 & 100 \\
\hline
\end{tabular}

Tablo 10’da görüldüğü gibi, “staj uygulamalarının haftada birkaç güne dağılmalıdır" ifadesine 21-23 yaş grubunun \% 62,5 'i, 25 ve üzeri yaş grubunun $\% 36,5$ 'i, 24-25 yaş grubunun ise \% 20'si katılmaktadır. Kararsızlık durumunun ise en fazla 24-25 yaş grubunda (\% 40) olduğu tespit edilmiştir.

Tablo 11: Öğretmenliğin Toplumda Saygınlığı Olan Bir Meslek Olma Durumu

\begin{tabular}{|c|c|c|c|c|c|c|}
\hline \multirow[t]{2}{*}{ Yanitlar } & \multicolumn{2}{|c|}{ 21-23 Yaş } & \multicolumn{2}{|c|}{ 24-25 Yaş } & \multicolumn{2}{|c|}{25 Yaş ve Üzeri } \\
\hline & Frekans & Yüzde & Frekans & Yüzde & Frekans & Yüzde \\
\hline $\begin{array}{l}\text { Kesinlikle } \\
\text { Kat1liyorum }\end{array}$ & 29 & 72,5 & 3 & 30 & 15 & 68,2 \\
\hline Kat1lyyorum & 9 & 22,5 & 6 & 60 & 6 & 27,3 \\
\hline Kararsızım & 2 & 5 & - & . & 1 & 4,5 \\
\hline Katılmiyorum & - & - & 1 & 10 & - & - \\
\hline $\begin{array}{l}\text { Kesinlikle } \\
\text { Katılmıyorum }\end{array}$ & - & - & - & - & - & - \\
\hline Toplam & 40 & 100 & 10 & 100 & 22 & 100 \\
\hline
\end{tabular}

$\mathrm{x}^{2}=12,842, \mathrm{SD}=6, \mathrm{p}=, 046$

Tablo 11'de görüldüğü gibi, “öğretmenlik toplumda saygınlığı olan bir meslektir" ifadesine 25 ve üzeri yaş grubunun $\% 95,5$ 'i, 21-23 yaş grubunun $\% 95$ 'i, 24-25 yaş grubunun ise \%90'1 katılmaktadir.

Tablo 12: Öğretmenlik Mesleğinin Popüler Olma Durumu

\begin{tabular}{|c|c|c|c|c|c|c|}
\hline Yanitlar & $21-23$ & Yaş & $24-25$ & Yaş & 25 Yaş $\mathrm{v}$ & e Üzeri \\
\hline & Frekans & Yüzde & Frekans & Yüzde & Frekans & Yüzde \\
\hline $\begin{array}{l}\text { Kesinlikle } \\
\text { Kat1lyyorum }\end{array}$ & 16 & 40 & - & - & 6 & 27,3 \\
\hline Kat1lyyorum & 10 & 25 & 5 & 50 & 8 & 36,4 \\
\hline$\overline{\text { Kararsızım }}$ & 12 & 30 & 2 & 20 & 6 & 27,3 \\
\hline Katılmiyorum & 2 & 5 & 3 & 30 & - & - \\
\hline $\begin{array}{l}\text { Kesinlikle } \\
\text { Katılmiyorum }\end{array}$ & - & - & - & - & 2 & 9 \\
\hline Toplam & 40 & 100 & 10 & 100 & 22 & 100 \\
\hline
\end{tabular}

Yukardaki tabloda görüldüğü gibi, "gelecekte öğretmenlik mesleği daha popüler olacaktır" ifadesine 21-23 yaş grubunun $\% 65$ 'i, 25 ve üzeri yaş grubunun $\% 63,7$ 'si, $24-25$ yaş grubunun ise \%50'si katılmaktadır. Kararsızlık durumunun ise en fazla 24-25 yaş grubunda (\%30) olduğu tespit edilmiştir.

Tablo 13'teki bulgulara göre, "staj uygulamaları muhasebe ve finansman derslerinde yapılmalıdır" ifadesine 24-25 yaş grubunun tamamı, 21-23 yaş grubunun $\% 92,5$ 'i, 25 ve üzeri yaş grubunun ise \%81,8'i katılmaktadır. Bu ifadeye ilişin kararsızlık durumu ise en fazla 25 ve üzeri yaş grubuna aittir $(\% 13,5)$.

Tablo 13: Staj Uygulamalarının Muhasebe ve Finansman Derslerinde Yapılma Durumu

\begin{tabular}{|c|c|c|c|c|c|c|}
\hline Yanitlar & $21-23$ & Yaş & $24-25$ & Yaş & 25 Yaș & ve Üzeri \\
\hline & Frekans & Yüzde & rekans & Yüzde & Frekans & Yüzde \\
\hline $\begin{array}{l}\text { Kesinlikle } \\
\text { Kat1lyyorum }\end{array}$ & 33 & 82,5 & 9 & 90 & 9 & 40,9 \\
\hline Kat1liyorum & 4 & 10 & 1 & 10 & 9 & 40,9 \\
\hline Kararsızım & 1 & 2,5 & - & - & 3 & 13,6 \\
\hline Katılmiyorum & 1 & 2,5 & - & - & 1 & 4,6 \\
\hline $\begin{array}{l}\text { Kesinlikle } \\
\text { Katılmıyorum } \\
\end{array}$ & 1 & 2,5 & - & - & - & - \\
\hline Toplam & 40 & 100 & 10 & 100 & 22 & 100 \\
\hline
\end{tabular}

\subsubsection{Bölüm Değişkenine Göre}

Bölüm değişkeni ile ankette yer alan maddeler arasındaki ilişkinin ki-kare analiz sonuçları Tablo 14'te verilmiştir.

Tablo 14: Bölüm Değişkeni İle Maddeler Arasındaki Ki-Kare Analizi Sonuçları

\begin{tabular}{|c|c|c|c|}
\hline & $\begin{array}{l}\text { Ki-kare } \\
\text { Değeri }\end{array}$ & & $\mathrm{p}$ \\
\hline $\begin{array}{l}\text { Pedagojik } \quad \text { Formasyon } \\
\text { öğretmenlik için gereklidir }\end{array}$ & 9,014 & 8 & ,341 \\
\hline $\begin{array}{l}\text { Pedagojik Formasyon eğitimi öğretmenlik } \\
\text { için yetersizdir. }\end{array}$ & 5,166 & 8 & ,740 \\
\hline $\begin{array}{l}\text { Muhasebe ve finansman bilgisi pedagojik } \\
\text { formasyon bilgisinden daha önemlidir. }\end{array}$ & 8,266 & 8 & ,408 \\
\hline $\begin{array}{l}\text { Pedagojik Formasyon derslerinin içeriği } \\
\text { güncel değildir. }\end{array}$ & 10,171 & 8 & ,253 \\
\hline 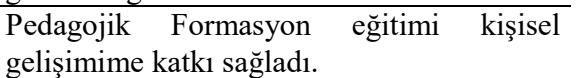 & 3,966 & 8 & 860 \\
\hline $\begin{array}{l}\text { Pedagojik formasyon eğitimi muhasebe ve } \\
\text { finansman bilgilerini öğretmenlikte nasıl } \\
\text { kullanacağımı gösteriyor. }\end{array}$ & 9,922 & 8 & ,271 \\
\hline 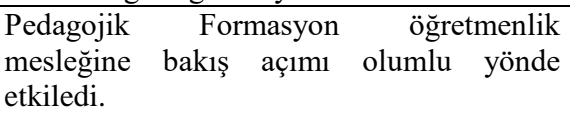 & 5,146 & 8 & ,742 \\
\hline $\begin{array}{l}\text { Pedagojik formasyon eğitiminde teoriye } \\
\text { ağırlık verilmektedir. }\end{array}$ & 9,621 & 8 & ,293 \\
\hline $\begin{array}{l}\text { Pedagojik Formasyon eğitiminde sınıf içinde } \\
\text { daha fazla uygulama yapılmalıdır. }\end{array}$ & 9,267 & 8 & ,320 \\
\hline $\begin{array}{l}\text { Staj uygulamaları haftada birkaç güne } \\
\text { yayılmalıdır }\end{array}$ & 11,940 & 8 &, 154 \\
\hline $\begin{array}{l}\text { İ̈BF mezunlarının formasyon eğitiminden } \\
\text { sonra iyi birer öğretmen olur. }\end{array}$ & 15,188 & 8 & ,056 \\
\hline $\begin{array}{l}\text { Öğretmenlik toplumda saygınlığ olan bir } \\
\text { meslektir. }\end{array}$ & 5,057 & 6 & 537 \\
\hline Öğretmenlik mesleğini çok seviyorum. & 4,081 & 4 & ,395 \\
\hline $\begin{array}{l}\text { Gelecekte öğretmenlik mesleğinin daha } \\
\text { popüler olacaktır. }\end{array}$ & 8,211 & 8 & ,413 \\
\hline $\begin{array}{l}\text { Öğretmenlik çok sıkıc1 ve sıradan bir } \\
\text { meslektir. }\end{array}$ & 8,491 & 6 & ,204 \\
\hline Fakültede aldığın & 2,589 & 8 & 957 \\
\hline
\end{tabular}


Hiçbir iş bulamazsam öğretmenlik yapmayı

düşünüyorum.

$4,266 \quad 8 \quad, 832$

Öğretmenlik çok fedakarlık gerektiren bir

$10,369 \quad 6 \quad 110$

meslektir.

$16,915 \quad 8,031 *$

Staj uygulamaları muhasebe ve finansman

derslerinde yapılmalıdır.

$\mathrm{p}<0,05$ ise $\mathrm{H} \_0$ ret

Yukarıdaki ki-kare analiz sonuçları incelendiğinde, bölüm değişkeni ile ankette yer alan maddelerden sadece "staj uygulamaları muhasebe ve finansman derslerinde yapılmalıdır" ifadesi arasında 0.05 anlam düzeyinde istatistiksel açıdan anlamlı bir ilişki bulunmuştur $\left(x^{2}=16,915\right.$ ve $p<0,05)$. Bölüm ile söz konusu ifade arasındaki çapraz tablo değerleri aşağıda verilmiştir.

Tablo 15: Staj Uygulamalarının Muhasebe ve Finansman Derslerinde Yapilma Durumu

\begin{tabular}{lcccccc}
\hline Yanıtlar & \multicolumn{2}{c}{ İsletme } & \multicolumn{2}{c}{ İktisat } & \multicolumn{2}{c}{ Maliye } \\
\hline & Frekans & Yüzde & Frekans & Yüzde & Frekans & Yüzde \\
\hline $\begin{array}{l}\text { Kesinlikle } \\
\text { Kat1liyorum }\end{array}$ & 28 & 75,7 & 22 & 73,4 & 1 & 20 \\
\hline Kat1lyyorum & 5 & 13,5 & 5 & 16,7 & 4 & 80 \\
\hline Kararsızım & 3 & 8,1 & 1 & 3,3 & - & - \\
\hline Katılmıyorum & - & - & 2 & 6,6 & - & - \\
\hline $\begin{array}{l}\text { Kesinlikle } \\
\text { Katılmıyorum }\end{array}$ & 1 & 2,7 & - & - & - & - \\
\hline Toplam & 37 & 100 & 30 & 100 & 5 & 100 \\
\hline
\end{tabular}

$\mathrm{x}^{2}=16,915, \mathrm{Sd}=8 \quad \mathrm{p}=, 031$

Yukarıdaki tabloda görüldüğü gibi, "staj uygulamaları muhasebe ve finansman derslerinde yapılmalıdır" ifadesine maliye bölümü öğrencilerinin tamamı, iktisat bölümü öğrencilerini $\% 90,1$ 'i, işletme bölümü öğrencilerinin ise \%86,2'si katılmaktadır. En fazla kararsızlık durumunun ise işletme bölümü öğrencilerinde $\left(\begin{array}{ll}\% & 8,1\end{array}\right)$ olduğu tespit edilmiştir.

\section{Sonuç}

$\mathrm{Bu}$ çalışmada, muhasebe ve finansman öğretmenliği için pedagojik formasyon eğitimi alan öğrencilerinin öğretmenlik mesleğine ve pedagojik formasyon eğitimine ilişkin algı düzeylerinin belirlenmesi amaçlanmıştır.

Araştırmaya katılan öğretmen adaylarının öğretmenlik mesleği ile ilgili genel olarak pozitif bir algıya sahip oldukları tespit edilmiştir $(=3,67)$. Elde edilen bu sonuç, İlğan ve Sevinç (2013) tarafından yapılan araştırma sonuçları ile benzerlik göstermektedir.

Araştırma sonuçlarına göre, katılımcıların büyük çoğunluğu (\%90) pedagojik formasyon eğitiminin öğretmenlik mesleğine bakış açılarını olumlu yönde etkilediği görüşündedirler. Bu sonucun Çetinkaya ve Hatay’ın (2016) araştırma bulguları ile paralellik gösterdiği görülmektedir. Diğer taraftan "pedagojik formasyon derslerinin içeriği güncel değildir" ifadesine öğretmen adaylarının sadece \%22,2'si katılmaktadır. Bu bulgular Taneri'nin (2016) araştırma sonuçları ile benzerlik arz etmektedir.

Araştırma sonuçlarına göre, öğretmen adaylarının büyük çoğunluğu $(\% 94,5)$ öğretmenliğin toplumda saygınlığı olan bir meslek olduğunu ve yine büyük bir çoğunluğu $(\% 97,2)$ öğretmenlik mesleğini çok sevdiğini ortaya koymaktadır. Ayrıca öğretmen adayları, öğretmenliğin çok sıkıcı ve
Sıradan bir meslek olmadığı, gelecekte daha popüler olacağ ve çok fedakârlık gerektiren bir meslek olduğu görüşünde birleşmektedirler. Tespit edilen bu bulgular Ö̈zkan (2012) tarafından yapılan araştırma sonuçları ile paralellik göstermektedir.

Araştırmada, eğitim fakültesinde verilen pedagojik formasyon eğitiminin öğretmenlik için hem gerekli hem de yeterli olduğu sonucuna varılmıştır. Ayrıca öğretmen adayları muhasebe ve finansman bilgisinin formasyon bilgisinden daha önemli olduğunu görüşündedirler. Kilis ilinde 2016-2017 eğitim - öğretim y1lında öğretmen adaylarının 33'ü staj uygulamalarını ticaret lisesinde yaparken, diğerleri Milli Eğitim Bakanlığı'na bağlı çeşitli okullardaki matematik dersinde yapmaktadırlar. Öğretmen adaylarının tamamına yakını bu uygulamanın ticaret liselerinde yapılması gerektiği görüşündedirler.

Sonuç olarak, öğretmen adaylarının Kilis 7 Aralık Üniversitesi Muallim Rifat Eğitim Fakültesi'nde verilen pedagojik formasyon eğitimine ve öğretmenlik mesleğine ilişkin pozitif bir algıya sahip oldukları görülmektedir. Ancak bu pozitif algının arttırılması için öğretmen adaylarının staj uygulamalarını matematik dersi yerine, ticaret liselerindeki muhasebe ve finansman derslerinde yapmaları daha yararlı olacaktır. Ayrıca formasyon eğitimine öğrenci kabulünde, genel not ortalaması ile birlikte, öğrencilerin muhasebe ve finansman bilgilerini ölçen bir sınava tabi tutulmaları faydalı olabilir. Çünkü bazı bölümlerde muhasebe ve finansman derslerinin sayısı yetersizdir. Buna bağlı olarak muhasebe ve finansman öğretmeni olduklarında adayların bilgilerinin yetersiz kalma durumu ortaya çıkabilir. Nitekim bu durumun araştırma sonucuna da yansıdı̆̆ı görülmektedir.

$\mathrm{Bu}$ araştırma, sadece Kilis 7 Aralık Üniversitesi Eğitim Fakültesi'nde pedagojik formasyon programına devam eden öğrenciler ile gerçekleştirildiği için sınırlılık taşımaktadır. Araştırma, farklı üniversitelerde muhasebe ve finansman öğretmeni olmak için pedagojik formasyon eğitimi alan öğrencileri kapsayacak şekilde genişletilerek yeniden yapılabilir. Bu sınırlılığa rağmen çalışmanın literatüre katkı sağlayacağı beklenmektedir.

\section{Kaynakça}

Altınkurt, Y., Yılmaz, K., \& Erol, E. (2014). Pedagojik Formasyon Programı Öğrencilerinin Öğretmenlik Mesleğine Yönelik Motivasyonları. Trakya Üniversitesi Eğitim Fakültesi Dergisi, 4(1), 48-62.

Çetinkaya, S., \& Hatay, F. (2016). Pedagojik Formasyon Sertifika Programı Öğrencilerinin Öğretmenlik Mesleğine Yönelik Tutum ve Aidiyet Duygularının Gelişmesinde Formasyon Eğitiminin ve Öğretmenlik Uygulaması Dersinin Etkisi. II. Uluslararası Türk Kültür Coğrafyasında Eğitim ve Sosyal Bilimler Sempozyumu, Nizip.

Dadandı, İ., Kalyon, A., \& Yazıc1, H. (2016). Eğitim Fakültesinde Öğrenim Gören ve Pedagojik Formasyon Eğitimi Alan Öğretmen Adaylarının Öz-Yeterlik İnançları. Kaygı Düzeyleri ve Öğretmenlik Mesleğine Karşı Tutumları. Bayburt Eğitim Fakültesi Dergisi, 11(1), 253-269. 
İlğan, A., \& Sevinç, Ö. Ş. (2013). Pedagojik Formasyon Programı Öğretmen Adaylarının Mesleki Tutum ve Çağdaş Öğretmen Algıları. Ondokuz Mayls Üniversitesi Eğitim Fakültesi Dergisi, 32(2), 175-195.

Kartal, T., \& Afacan, Ö. (2012). Pedagojik Formasyon Eğitimi Alan Öğretmen Adaylarının Öğretmenlik Mesleğine İlişkin Tutumlarının İncelenmesi. Mehmet Akif Ersoy Üniversitesi Eğitim Fakültesi Dergisi, 12(24), 76-96.

MEB (2014), Millî Ë̆itim Bakanlı̆̆ Öğretmenlik Alanlarl, Atama ve Ders Okutma Esaslart. (Erişim: 01.03.2017), http://ttkb.meb.gov.tr/meb_iys_dosyalar/2016_08/08032 940_9_cizelgeveesaslar.pdf

Özer, E. (2016). Pedagojik Formasyon Programı Öğrencilerinde Temel Benlik Değerlendirmesi, Başa Çıkma Stratejileri ve Yaşam Doyumu. The Journal of Academic Social Science Studies, II.125-139.

Özkan, H. H. (2012). Öğretmenlik Formasyon Programındaki Öğretmen Adaylarının Öğretmenlik Mesleğine İlişkin Tutumlarının İncelenmesi (SDÜ Örneği). Ahi Evran Üniversitesi Kırşehir Eğitim Fakültesi Dergisi (KEFAD), 13(2), 29-48.

Polat, S. (2013). Pedagojik Formasyon Sertifika Programı ve Eğitim Fakültesi Öğrencilerinin Öğretmenlik Mesleğine Yönelik Tutumlarının İncelenmesi. E- International Journal of Educational Research,4(2), 48-60.

Taneri, P. O. (2016). Öğretmen Adaylarının Pedagojik Formasyon Sertifika Programının Niteliği Hakkındaki Görüşleri (Çankırı İli Örneği). Kastamonu Eğitim Dergisi, 24(3).

Weiers, R. M. (2008). Introduction to Business Statistics. USA: South Western Cenage Learning.

Yalçın İ. E., \& Akay, C. (2015). Eğitim Fakültesi ve Pedagojik Formasyon Sertifika Programlarında Öğrenim Gören Öğretmen Adaylarının Öğretmenlik Mesleği Yeterliklerine Yönelik Görüşleri. Ahi Evran Üniversitesi Kırşehir Eğitim Fakültesi Dergisi, 16 (2), 179-197.

Yıldırım, İ., \& Vural, Ö. F. (2013). Türkiye'de Öğretmen Yetiştirme ve Pedagojik Formasyon Sorunu. Journal of Teacher Education and Educators, 3(1), 2014, 73-90.

Yıldız, S. (2016). Pedogojik Formasyon Eğitimi Alan Öğrencilerin Uzaktan Eğitime Yönelik Tutumları. $A \dot{I} B \ddot{U}$ Sosyal Bilimler Enstitüsü Dergisi, 16(1), 301-329. 